\title{
Balkan Migration Crises and Beyond
}

\author{
Anna Krasteva \\ Policy and Citizens Observatory: Migration, Digitalization, Climate, Sofia, \\ Bulgaria \\ anna.krasteva@gmail.com
}

\begin{abstract}
This article has a threefold aim. First, to create a typology of Balkan migration crises. Second, to reflect on how migration is theorized in a crisis situation by analyzing the competing conceptual clusters and proposing new ones. Third, to measure the ratio between the region's crisis and anti-crisis potential in the field of migration in regard both to agency and policies. The article is structured in four parts. The first part reconstructs the conceptual history of "crisis" and its affirmation as the hegemonic discourse of contemporary times. The second part introduces temporality as a theoretical zoom that illuminates a different migration profile depending on whether we are observing it in a short-term, mid-term, or long-term perspective. The third part presents a new typology of Balkan migration crises based on different criteria. It structures Balkan migration crises into two clusters: real and constructed. The article seeks to answer the question of why, given the abundance of real refugee and migration crises, new ones are constructed. The fourth part goes beyond the crisis and analyzes the migration and development nexus as a major policy innovation. The conclusion offers a comparative analysis of the diverse Balkan migration crises.
\end{abstract}

\section{Keywords}

migration - refugees - crises - refugee crisis - Balkans - South Eastern Europe migration and development nexus 


\section{Introduction*}

"Here is Serbia, whether it is a war, sanctions, Kosovo, it mostly works the same way. People say - the crisis in Serbia, it is not the crisis, it is simply Serbia." This statement by a Serbian refugee in Belgrade who fled from Bosnia and Herzegovina in 1993 illustrates three phenomena: the multiplicity and omnipresence of crises in the Balkans; the systemic affinity between migration and crisis; and the embeddedness of (migration) crises in national identity. Russel King (2005) has defined Albania as a laboratory for the study of migration because of the series of migration crises the country has been through since 1990. This definition is largely valid for the whole region. At the beginning of the 199os, the Western Balkans produced the most intensive forced migrations in Europe after the Second World War, while two decades later the Balkan refugee route (2015-2016) became an epitome of global, European, and regional challenges, and of the mismanagement of a migrant crisis. The Western Balkans are characterized by a very complex jigsaw of security and sovereignty issues and of intensive refugee and migration flows from, to, and within the region, all in a situation of post-conflict reconstruction. The Western Balkans are aspiring to EU membership, but the region is fragmented by the different stages of EU integration of the different countries - from potential candidates to current candidates to full members. This puzzle poses a true challenge to migration crisis management and migration policies at the national, regional, and European levels.

This article has a threefold aim. First, to create an original typology of Balkan migration crises. Second, to reflect on how migration is theorized in a crisis situation by analyzing the competing conceptual clusters and proposing new ones. Third, to measure the ratio between the region's crisis and anti-crisis potential in the field of migration in regard both to agency and policies. Migration crises are political crises. The political is understood in a twofold perspective: policies manage migration and define priorities; politics frames migration and forges messages.

The article is structured in four parts. The first part reconstructs the conceptual history of "crisis" and its affirmation as the hegemonic discourse of contemporary times. The second part introduces temporality as a theoretical

* The article is developed thanks to the author's participation in the projects: ReCriRe. Representation of the Crisis and Crisis of Representation (H2O2O); Maximizing the Development Impact of Labor Migration in the Western Balkans; Matilde (H2O2O). Migration Impact Assessment towards Integration and Local Development in European Rural and Mountain Regions (MATILDE has received funding from the European Union's Horizon 2020 research and innovation programme under grant agreement No 870831). 
zoom that illuminates a different migration profile depending on whether we are observing it in a short-term, mid-term, or long-term perspective. The third, most extensive, part presents a new typology of Balkan migration crises based on different criteria: causes, duration, sending and receiving countries, nationality of the migrants, key actors of the (mis)management of the crises, and real or constructed character of the crisis. It structures Balkan migration crises into two clusters: real and constructed. The article seeks to answer the question of why, given the abundance of real refugee crises, new ones are constructed. The fourth part goes beyond the crisis and analyzes the migration and development nexus as a major policy innovation. The conclusion offers a comparative analysis of the diverse Balkan migration crises.

The first part of the article presents the conceptual framework of this study, examining the transformation of crisis from a marginal concept into a fundamental mode of interpreting contemporary society.

The etymology of the term "crisis" refers to two clusters of meanings: voluntaristic (associated with the need of decision-making) and agonistic (associated with conflict). The centuries after Greek Antiquity would specify the meaning of the term, focusing it on instability, risk, discontinuities, but they would also adopt the Ancient Greek intuition about the key role of decision-making and action: "Speaking of crisis of whatever nature, we convey firstly the feeling of uncertainty, of our ignorance of the direction in which the affairs are about to turn - and secondly the urge to intervene" (Bauman and Bordoni 2014: 7). The conceptual history of the term "crisis" is uneven, moving in ebbs and flows, with periods of marginalization followed by periods of active theorization: "The term 'crisis' was in only marginal use until the mid-18th century when it rose to prominence, 'a structural signature of modernity' (Reinhart Koselleck)" (Schulz 2017:10). There is a close connection between crisis and socio-political change: radical transformations such as the great American and French revolutions have been conceptualized by the authors of the era as crises (ibid.); Karl Marx's attention was focused on the recurrent crises of capitalism.

Nowadays, crisis has been assigned a central place in the conceptual arsenal by which the contemporary world is conceived. "An epoch is often characterized by the domination of a self-interpretation of its relation to historical change" (Schulz 2017: 9). The 2oth century ended with a radical non-crisis discourse: Francis Fukuyama's (1992) "end of history" expresses the triumph of democracy and globalization, their victory over aberrations like communism, and the advancement of politics and society towards a shared horizon. The 
21st century has replaced Fukuyama's triumphant optimism with Zygmunt Bauman's "state of crisis" as the differentia specifica of contemporary society. Zygmunt Bauman and Carlo Bordoni make the transition from ad hoc to permanent crisis, from crisis as a pathology to crisis as the new normality: "We must learn to live with the crisis, just as we are resigned to living with so much endemic adversity imposed on us by the evolution of the times: pollution, noise, corruption and, above all, fear." (Bauman and Bordoni 2004: 7). In the same vein the endless crisis is conceived as the modern experience of time: "The crisis is dominating without control in all spheres of reality ... the crisis is the general rule that is expected to form individual and collective consciousness as well as the modalities of public policies ... which turns the crisis into a normal, regular and permanent situation" (Revault d'Allonnes 2012: 18).

In addition to the "state of crisis" thesis, another two trends in the contemporary conceptual dynamic of the notion of "crisis" (Krasteva 2019a) are key to understanding the migration crisis: the transitions from hard determinants to contingency; from social and political ontology to narratives. "At first sight, there is nothing more legitimate than linking crises to their 'determinants,' to their 'historical sources,' their 'origins,' their 'conditions of emergence' or of production" (Dobry 2009: 1417 of 6787, Kindle ed.). Precisely this analytical legitimacy is contested by Michel Dobry, who even calls the search for the causes of crises "a pure etiological illusion" that hinders crisis studies in direct proportion to the extent to which it is assumed to be self-evident and "beyond any methodological doubt" (ibid.: 1434). M. Dobry counters the dominant etiological approach, according to which crisis management and prevention requires knowing the causes of crises, by his own approach, which maximally distances crisis studies from determinism, immersing crises in contingency by conceiving them "as not necessary, as thoroughly inhabited by contingency" (ibid.: 87). The causes vs contingency debate is interesting for understanding the two different migration crises - real and constructed - as well as a first step towards the liquefaction of the crisis. A second step in this direction is the conceptualization of crises as narrative: "The narratives of crisis express the experience of living in a global and universal crisis. According to these narratives, crises are the normality and the 'reality principle' (Freud) of the contemporary world" (Spurk 2017: 67). Key to my analysis is the emphasis on the performative character of narratives: "The crisis discourse is not innocent, it does not limit itself to describing a configuration of events objectively present in reality; it contributes to constituting it socially, to imposing it in the public debate and to generating representations, emotions and provisions specific to certain reforms" (Eraly 2017: 51). The liquefaction of the crisis in discourses has two fundamental consequences: debordering the crisis, blurring the borders of 
the phenomenon, which opens up a theoretical and policy horizon for a transition from ad hoc to permanent crisis; and privileging of the more powerful producers of discourses - authoritative authors - and mobilization of crisis discourses for their purposes. This idea is developed in the author's conception of the post-democratic crisis (Krasteva 2019b).

The post-democratic crisis is theorized in the analytical triangle of postdemocracy - post-truth - mega leadership. The major controversy in migration policy today is the one between post-truth politics and evidence-based policymaking (Ruhs, Tamas, and Palme 2019). A significant characteristic of the post-democratic crisis is its growing dissociation from ontological reality the political crisis over migration is reaching white-hot peaks despite the decline of migration flows. The post-democratic crisis is liquefied - it depends less and less on external manifestations and determinants, and more and more on the voluntaristic strategies of leaders. The systemic affinity between crises and leadership is taking on new forms, conceptualized in the paradox "If crises did not exist, populist leaders would have invented them." It paraphrases Sartre, emphasizing that populist leaders need crises as deeply and intimately as Sartre's anti-Semites needed the Jews. Migration/refugee crises are their favourite asset (Krasteva 2019b).

The author's conception of the post-democratic crisis is applied to Balkan migration crises so as to identify and highlight their differentiation and multiplication. The author does not agree with Michał Krzyżanowski, Anna Triandafyllidou, and Ruth Wodak's (2018) diagnosis that the concept of "refugee crisis" is wrong. This article proposes a more complex conception of two types of migration/refugee crises: real and populist. The first type borrows two elements of the Iom definition of "migration crisis" involving large-scale migration flows and migration management challenges ${ }^{1}$ - namely, an unprecedented increase of refugee flows and institutional incapacities in managing them efficiently. The second type is of a different character and is constructed through politicization, mediatization, and securitization. Securitization represents migration as a security problem, as an existential threat to the state, territory, and society (Buzan, Wæver, and de Wilde 1998), which gives rise to the "politics of fear" (Wodak 2015).

1 https://www.iom.int/mcof. 


\section{Temporality - Theoretical Zoom on Different Regional Migration Profiles}

The temporality and migration nexus is a relatively new arena in migration scholarship (Gardiner Barber and Lem 2018; Cwerner 2001). This nexus forms different conceptual clusters. The biggest cluster is with agency, subjectivity, and capacity to act in migration processes, where the nexus is conceived as a feature of migrant experience shaped by the political, economic, and securitarian order (Andersson 2014; Gardiner Barber and Lem 2018; Baas and Yeoh 2019). The temporality and migration nexus forms another conceptual cluster with modernity where it is linked to globalization, nation-states, multicultural societies, and the neo-liberal order (Cwerner 20o1; Castles, Haas, and Miller 2014). Both clusters are relevant in analyzing migrations in the Balkan region of post-conflict reconstruction, creation of new states, and redefinition of the role of agency in this dynamic geo-political context.

In this article, however, temporality is introduced in another theoretical perspective. The different types of temporality are conceived of as a theoretical zoom that outlines a different migration profile depending on whether we are zooming out and taking the long-term perspective in order to observe the mega-trends, or zooming in and taking the short-term perspective in order to see emerging and micro-trends, as well as ad hoc migration events. This analysis is based on Fernand Braudel's concept of the different types of temporality. The history of migrations, just as any history, "is concerned with breaking down time past, choosing among its chronological realities according to more or less conscious preferences and exclusions" (Braudel 1980: 27). Braudel distinguishes two poles of time, two different types of temporality. The first one is the long time span, the longue durée. The second temporality is the instant. The longue durée refers to mega-trends and structures; the short time span is "proportionate to individuals, to daily life, to our illusions" (ibid.: 28). The attention of contemporaries is focused precisely on events: "an event is explosive, a 'nouvelle sonnante' ('a matter of moment') as they said in the sixteenth century. Its delusive smoke fills the minds of its contemporaries, but it does not last, and its flame can scarcely ever be discerned" (ibid.: 27). Most events do not last, they do not leave a trace and can be insignificant in a historical perspective, but they are important for politics and for individuals. In-between the two poles of time, the long-term and the short-term, Braudel situates the conjunctural temporality: "A new kind of historical narrative has appeared, that of the conjuncture, of the cycle, and even of the 'intercycle, covering a decade, a quarter of a century" (ibid.: 29). These three types of temporality are necessary as a precaution against allowing the theoretical attention to be usurped by the most dramatic events and the loudest actors, and ensuring that it is evenly 
TABLE 1 Migration profile according to different temporalities

\begin{tabular}{llll} 
Type of history & Temporality & Migration profile $\begin{array}{l}\text { Dominant type } \\
\text { of migration }\end{array}$ \\
\hline $\begin{array}{l}\text { Structural } \\
\text { Conjunctural }\end{array}$ & $\begin{array}{l}\text { Longue durée } \\
\text { Mid-term }\end{array}$ & $\begin{array}{l}\text { Emigration } \\
\text { Migration \& } \\
\text { refugee crisis } \\
\text { Outbreaks }\end{array}$ & $\begin{array}{l}\text { Labour } \\
\text { Refugees }\end{array}$ \\
Episodic history & $\begin{array}{l}\text { Unique } \\
\text { contingent events }\end{array}$ & & \\
\hline
\end{tabular}

SOURCE: CREATED BY THE AUTHOR BASED ON FERNAND BRAUDEL'S CONCEPT OF PLURAL HISTORY, AND ITS APPLICATION TO MIGRATIONS IN THE WESTERN BALKANS

distributed: "do not think only of the short time span, do not believe that only the actors which make the most noise are the most authentic - there are other, quieter ones too" (ibid.: 38).

This article applies Braudel's typology of temporalities with a twofold aim: to focus analytically on the kaleidoscope of migration phenomena, and to identify those that fit into a short time span and those that form long cycles or trends; and to find out which time span is relevant to migration crises. This study is not historical, it is politological and in it history is understood, following Lucien Febvre, as "History, science of the past, science of the present" (Braudel 1980: 38).

Our temporal zoom-in on migration has identified the dominant migration profile and the corresponding key type of flows in the Western Balkans. Table 1 sums up this classification. It is based on the types of history defined by Fernand Braudel (1980: 27-30) and their corresponding temporality. In the longue durée of structural history, emigration is at the centre of the migration profile which is characterized by labour migration from and within the Western Balkan region. Conjunctural history, with a mid-term perspective, is marked by refugee crises involving refugee flows that differ in origin, composition, and destination. Episodic history is the relevant perspective for explaining migration outbreaks, such as sudden flows of irregular migrants from Kosovo and Albania to Germany - welling up suddenly and petering out comparatively fast as a result of measures to restrict them in both the receiving and sending countries (Krasteva et al. 2018).

The analysis borrows from complexity theory (Mitchell 20o9) two types of explanation: "big causes" for the longue durée migrations and "small causes" for migration outbreaks; a more linear dynamic in the first case, non-linearity, self-organization, and emergence in the second (Ejdus and Rečević 2021). Emergence - a key concept of complexity theory - is crucial for the understanding of both mid-term and ad hoc migrations: "Emergent phenomena 
are open, adaptive, self-organized, and non-linear. Emergence implies selforganization from below through adaptation to the internal and external environment and co-evolution or the ability to transform with the environment" (Kavalski 2007: 440).

\subsection{Emigration-Crisis and Anti-crisis Potential}

Emigration is the differentia specifica of the Balkan migration profile. In a quarter of a century the Western Balkans experienced an emigration rate of $28 \%$ of its current population. Bosnia and Herzegovina is the country with the highest emigration rate $(43 \%)$ compared to its population in 2015 . Albania has more than $39 \%$ of its population living outside its territory. Albania currently has one of the world's highest emigration rates, with more than 1.25 million emigrants in 2017. ${ }^{2}$ During 2007-2012, Albania was ranked 4th in Europe and 14th in the world by net migration rate per 1,0oo inhabitants. ${ }^{3}$ In North Macedonia the emigration rate has reached $25 \%$, in Montenegro $22 \%$, and in Serbia $11 \%$. In Kosovo's case, the total number of emigrants abroad is estimated at more than 610,00o, representing $34 \%$ of Kosovo's current population (Krasteva et al. 2018: 91-92).

If in a temporal perspective emigration is undoubtedly the longest-term migration phenomenon, its relation to the crisis is twofold. The political, media, and scholarly discourses distinguish two key aspects of its crisis potential: brain drain and irregular migration. The emigration of the best and the brightest, that is, youth emigration, is often experienced as a loss and trauma as both a family and national trauma. Irregular migration is asymmetrically distributed: Albania remains at the top of the list of countries by number of people illegally crossing land borders (Krasteva et al. 2018). Although it is not characteristic of the whole region, irregular migration remains a serious challenge for Albania and Kosovo.

Labour migration also has a strong anti-crisis potential. It plays a significant role in reducing unemployment and remains a crucial livelihood strategy for the Western Balkan countries (Krasteva et al. 2018). The developmental potential of migration is beneficial for both sending and receiving countries: recent studies on the migration flows in the Adriatic-Ionian and Danube macro regions demonstrate the role of migration as an alleviating factor for addressing depopulation and for enhancing the territorial cohesion (ESPON EGTC 2018).

2 INSTAT,Tirana 2018.http://databaza.instat.gov.al/pxweb/sq/DST/START_MM/NewMIMooo3/ table/tableViewLayout2/?rxid=854adfdo-5bde-4532-874d-oogbeb2a9681.

3 World Bank, 2012. https://en.wikipedia.org/wiki/List_of_countries_by_net_migration_rate\# World_Bank_(2012). 
There is hardly another region of the world where the current situation of migrations is still considerably influenced by the past history as in the Balkans. Migrations have been a fundamental element in the history of the Balkans, accompanying its stormy events ...

BONIFAZI AND MAMOLO 2004:519

The three-decade period from the beginning of the 199os to the present is characterized by multiplication and diversification of refugee crises:

- 1991-2001: Yugoslav wars and conflicts.

- 2015-2016: Western Balkan refugee route.

- Recent years: Inward and outward migration outbreaks.

- Fluid political temporality: The populist migration crisis.

The Western Balkans: Migration "Champion" during the Yugoslav Wars and Conflicts (1991-2001)

The Western Balkans (with the exception of Albania) have become the migration champion of Europe, creating the largest flows of forced migrations in post-war Europe (Laczko, von Koppenfels, and Barthel 2002; Baldwin-Edwards 2005; Krasteva 2015), a serious source of security risks. The wars in Croatia, Bosnia and Herzegovina, and Kosovo produced about 2.4 million refugees and 2 million internally displaced persons (Watkins 2003: 10). Since the outbreak of the Bosnian War in 1992, as many as 2.2 million people - half of the pre-war population of Bosnia and Herzegovina - have been forcefully displaced, more than a million of them as refugees. Serbia hosted 700,000 Serb refugees or internally displaced persons from Kosovo, Croatia, and Bosnia (Rowland 2000). Serbia became the European country with the largest number of refugees per capita (Krasteva 2015). Since the breakup of Yugoslavia, Serbia has been one of the world's main countries of origin of refugees, as well as one of the most important host countries (Lažetić 2018: 17). The Croatian war of independence caused 500,000 refugees and displaced persons (Frucht 2005). 247,000 Croats and other non-Serbs were displaced during the war from or around the Republic of Serbian Krajina (Croatia Human Rights Practices 1993). In 1991, during the conflict in Eastern Slavonia, 80,00o Croats were forced to leave the region (Human Rights Watch 1997). Croatia became a major host country, with 287,00o refugees, mainly from Bosnia, Vojvodina, and Kosovo, and 344,000 IDP s in 1993. UNHCR ranked it number 7 in the list of top refugee host countries (UNHCR 1993). The Kosovo War caused 862,979 Albanian 
refugees and 500,000 to 600,000 IDP s (Iacopino et al 2001). After the end of the war, Albanians returned, but over 200,00o Serbs, Romani, and other nonAlbanians fled Kosovo (Rowland 2000). The Albanian-Macedonian conflict in 2001 provoked the displacement of 170,000 people, 74,000 of whom were displaced internally (UNHCR 2004). The migration profile of the Western Balkans in this period differed radically both from the European migration profile and from that in the Eastern Balkans. Whereas in the Eastern Balkans the majority of migrants were labour migrants, in the Western Balkans of the early 199os the pendulum swung in the polar opposite direction - refugees, internally displaced persons, ethnic migrations, and human trafficking took centre stage.

\subsection{The Western Balkan Refugee Route (2015-2016)}

The Syrian refugee crisis placed the Western Balkans at the hot intersection of the conflict in the Middle East and the European policy of crisis (mis)management. Balkan scholars have defined the latter as a "disaster of European refugee policy" (Žagar, Šalamon, and Hacin 2018). My own assessment is more balanced - the discontinuities and deficits in the European asylum policy were due to the difficult balance between security policies and humanitarian concerns, between European and national priorities, and between European response and externalization of the refugee crisis management.
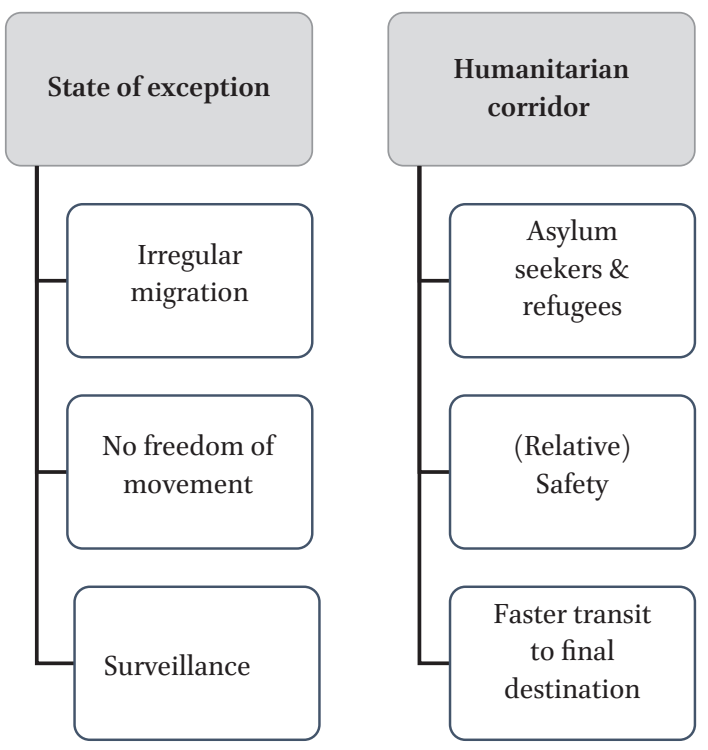

FIGURE 1 Two narratives of the Balkan refugee route 
The duration of the Balkan refugee route was wholly politically defined - it had to do less with the development of the refugee crisis than with the latter's European (mis)management. The Balkan refugee flow lasted for half a year from September 2015 to March 2016 - and more than a million migrants passed towards Western Europe (Ejdus and Rečević 2021: 5). Its intensity was a major challenge for border authorities: "By June 2015 there were 400 persons entering [North Macedonia] on a daily basis from Greece" (MIGREC 2020: 133). The flows illustrated the dramatic character of the Syrian refugee crisis - some one million refugees passed through North Macedonia, and more than 650,000 through Croatia (ibid.: 63). In 2015 and the first quarter of 2016, more than 920,0oo refugees and migrants - primarily from Syria, Afghanistan, and Iraq passed through Serbia on their way to Central Europe (Lažetić 2018: 17). More than 660,00o refugees passed through the Croatian part of the corridor, with around 5,00o daily arrivals (Župarić-ljjić and Valenta 2019).

How can one conceptualize the "refugee corridor," this unprecedented ad hoc policy of managing refugee flows during a severe migration crisis? Two conceptual clusters offer alternative interpretations - the state of exception and the humanitarian corridor (see Figure 1).

The first narrative defines the Balkan route as "a very disorganized form of a 'state of exception'” (Žagar, Šalamon, and Hacin 2018: 39), criticizing the policy of surveillance, of denying freedom of movement, and of channelling refugees along permitted transport corridors. This theoretical rapprochement is theoretically questionable with regard to both concepts: the humanitarian corridor is indeed a policy of exception, but one that is maximally close to the interests of asylum seekers as it ensures them the fastest and safest possible passage via transit countries and arrival at the desired destination without the "services" of people smugglers; conversely, Giorgio Agamben's state of exception conceptualizes dramatic realities whose space are camps, where the human condition is degraded to the extreme and transformed into "conditio inhumana" (Krasteva 2019a).

\subsection{Migration Outbreaks - in and out}

The migration outbreaks of recent years are the most heterogeneous. They differ by cause, origin, and destination, as well as by intensity.

Bosnia and Herzegovina has become a transit country for migrants heading towards Western Europe since early 2018 (Stanicek 2019), and the trend is intensifying (Hodžić 2020). B\&H is part of several migration routes: a) Greece - Albania - Montenegro - B\&H - Croatia and other EU countries; b) Greece - Macedonia - Serbia - B\&H - Croatia and other EU countries; c) Greece - Bulgaria - Serbia - B\&H - Croatia and other EU countries (ibid.: 83). The majority of migrants 
$(87 \%)$ come from Pakistan, Afghanistan, Iraq, Morocco, Syria, Bangladesh, Algeria, and Iran. The arrivals from Syria are decreasing (ibid.: 87). At the end of 2020, some 10,000 migrants from Asia, the Middle East, and North Africa were stuck in B\&H (DW 202O). Reception capacities were expanded using EU funds, but remain insufficient (Stanicek 2019). "The European Union has described Bosnia's migrant situation as 'alarming,' after the bloc had assisted the Balkan country with at least $€ 85$ million since 2018" (DW 2021).

Kosovo is faced with a double challenge: migration outbreaks of Kosovars to Western Europe, mostly to Germany, and irregular migration to Kosovo. The latter is significantly smaller in number. Kosovo is not an important part of the Balkan route, but recent years have seen an increase in the migration flow: "the numbers of asylum seekers in Kosovo have tripled over the last years, from about 600 applications in 2018, to 2,000 applications in 2019" (MIGREC 2O2O: 84).

Albania also faces a double challenge: a relatively high and increasing number of asylum applications in the $\mathrm{EU}$ (from 16,950 in 2014 to 24,600 in 2017) with a peak of 67,95 o in 2015, mostly in Germany. In 2015, Albania was among the top five origin countries of asylum applicants in the EU (Krasteva et al. 2018: 21).

Montenegro is not part of the traditional Balkan route, and until 2017 the number of migrants to the country was relatively low. In the last few years, however, Montenegro has emerged as a transit country, with "an $87 \%$ increase on the number of detected irregular migrants in 2019 (8,685 migrants), in comparison with the previous year (4,645 migrants)" (MIGREC 2020: 104). Most of the migrants came from Morocco, a relatively rare country of origin of Balkan flows. This new trend is the result of "the closure of the 'traditional' Balkan route through North Macedonia, which stimulated the shift of itinerary to Europe through the so-called 'coastal route' or 'Adriatic route,' which involves crossing through Albania, Montenegro, and Bosnia and Herzegovina" (ibid.: 103).

North Macedonia has become a transit destination for migrants from Pakistan, Afghanistan, and Iran - approximately 38,ooo in 2019 (MIGREC 2020: 134).

\subsection{Populist Migration Crisis - between Securitization and Ontological Insecurity}

He was me, yes. But I am not him.

NeIl gaiman, American Gods

The classic migration crisis is related to the populist migration crisis in the way the asymmetric identification in Neil Gaiman's quote indicates: the former is found in the latter, but the latter is not reduced to the former (see Figure 2). 


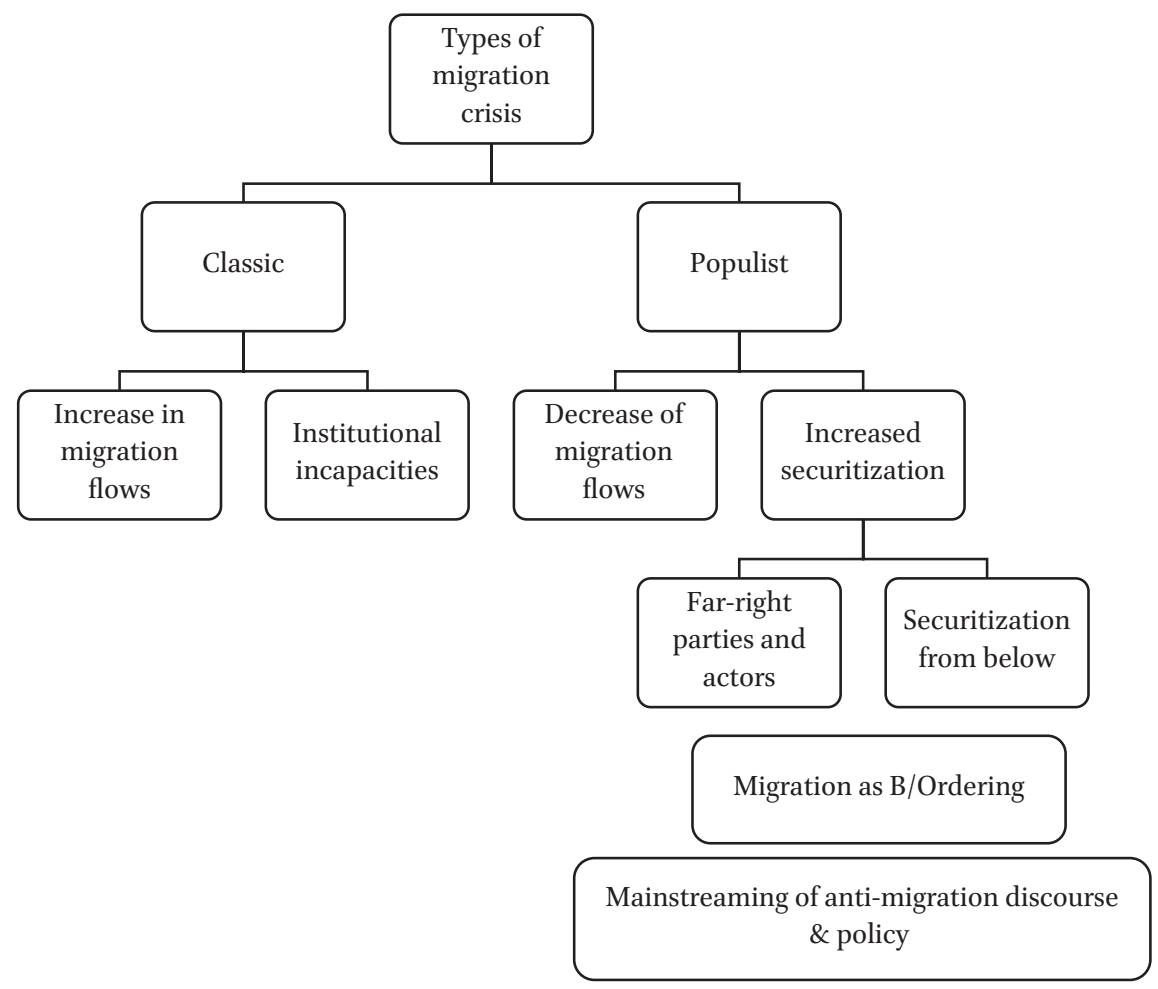

FIGURE 2 A taxonomy of migration crises

All previous migration crises involved a significant, or brief but drastic, increase in migration flows. The second policy aspect of the crisis - institutional incapacities for crisis management - is also found in most of the analyzed refugee crises, at least at the beginning. The populist migration crisis is different it is more independent from the ontological reality of the size and dynamic of migration flows; its emergence and development are associated with the political agency of securitization (Krasteva 2019b. Anna Triandafyllidou (2018) makes a similar distinction: refugee flows become a "crisis" when their "mediatization and politicization" in public and political discourse turn them into a crisis.

Agency is different in the two types of migration crisis. In the classic migration crisis, the key role is played by institutions - national, local, and European and migration management policies. In the populist migration crisis, the key role is played by securitizing actors - far-right nationalist parties and organizations and their anti-migration discourses, which often criminalize migration (Vezovnik 2018). 


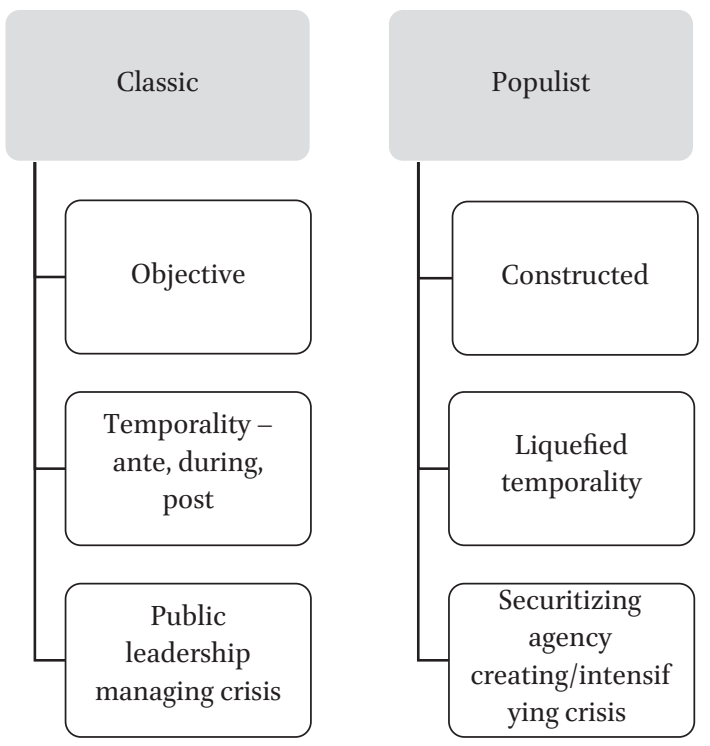

FIGURE 3 Comparison of the classic and populist migration crises

The securitization of migration unfolds in two directions, vertical and horizontal - from political actors towards citizens, and from small groups or local communities towards individuals, other groups, and society at large.

I will analyze the difference between the two types of migration crisis (see Figure 3), as well as the agency and mechanism of the constructed crisis, mainly on the basis of the Serbian case, examined in a comparative perspective with other countries of the region. The Serbian case is interesting for three reasons. The first is the intensity of the migration crisis. Serbia was one of the most affected countries on the Western Balkan route both during the acute phase, when almost one million refugees passed through the country from the Serbian-North Macedonian border on their way to Hungary or Croatia, and after the closing of the borders, when the number of stranded migrants reached 8,ooo, leveling off at 4,00o-6,ooo since then (Ejdus and Rečević 2021: 33). The second reason for interest in the Serbian case is political leadership. The position taken by Aleksandar Vučić was different from that of other leaders such as Viktor Orbán. Vučić and his government defined the crisis as "manageable and temporary," and took a humane and humanitarian approach towards crisis management: "Serbia initially did not join [the] anti-migrant hysteria which swept through Europe in 2015. Firmly condemning the walls and fences on the borders and restating its 'open-door-assistance-transit-policy' ..., the government ... improved the image of Serbia in the EU" (ibid.: 34). The countries of the region took different positions 
along the axis of humanitarianism-securitization of the refugee crisis: "Hungarian, Macedonian and Slovenian policies have been designated as more security-oriented in comparison to Serbia and Croatia, whose policies were arguably more humanitarian, at least in the initial phase of the corridor's existence" (Župarić-Iljić and Valenta, 2019: 133). Thirdly, the Serbian case illustrates the autonomy of the securitization of the refugee crisis vis-àvis the refugee crisis itself - the securitizing mobilizations were not provoked by the peak of the refugee crisis, they happened after it - the first episodic protests took place in 2017 , followed by a new wave of anti-migrant protests in late 2019 and the winter of 2019/2020 (Ejdus and Rečević 2021: 36).

\subsubsection{Populist Securitization}

The migration crisis was the crisis dreamed of by the far right throughout Europe - it catalyzed the emergence of far-right parties in countries like Germany and Spain, where such parties had been non-existent for decades, and the rise to power of leaders like Matteo Salvini. This author has conceptualized the systemic affinities between the migration crisis and populist leadership in the following provocative thesis: "If the migration crisis did not exist, it would have been invented by populist politicians" (Krasteva 2019b). The migration crisis does exist, but it is magnified by the far right for two reasons. The first is party-political - consolidation and increasing electoral weight. The second exists in the sphere of symbolic politics and is related to the far right's ambition to impose the securitarian interpretation of the migration crisis as the hegemonic interpretation in public debate.

Studies on the far right in the Western Balkans are still at an early stage (Lažetić 2018). For the purposes of this analysis, three aspects are important: the emergence of a "new" far right in Serbia; Serbia's transformation into a preferred place of the international far right for networking; public visibilization of the agency of vigilantes.

The migration crisis was used by the Serbian far right to rebrand itself. In the first half of the 199os, the Serbian far right fed on victimhood narratives, on the arrival of Serbian refugees from Bosnia, Croatia and Kosovo, who had been "expelled from their homes by ethnic enemies": "the refugees' traumatic negative experiences have arguably had a radicalizing effect on the Serbian society, providing support for the ideas and the agenda of the Serbian Radical Party" (Lažetić, 2018: 43). This nationalism was, and remains, anti-Western. It transformed the affective energy of victimization narratives into resentment against NATO, which bombed Serbia, and against the West, which supports Kosovo. The migration crisis allowed the Serbian far right to recalibrate its target, shifting the focus from Serbia's neighbours as ethnic 
enemies to the refugees from the Middle East and Asia - which has brought it close to the European far right. This new brand, as well as the transition from anti-Westernism to anti-immigration rhetoric, are elements of the Serbian far right's strategy for its repositioning and Europeanization:

In Russia and Serbia, the reason for transition from [an] anti-Western to anti-immigration focused agenda was to ensure the relevance of far right actors in the global arena. Far right thinkers such as Dugin have understood that [the] anti-Western agenda is no longer useful in the changing geopolitical order and climate. Transitioning to the anti-immigration platform was a far more useful project, as it allowed the same arguments to be made from a different perspective and with a network of international movements to back it up.

LAŽETIĆ 2018: 57

Serbia did not merely join the international networks of the far right, it began to turn into one of the latter's favourite centres: "Nationalists from across Europe have started arriving in Serbia to support one of the few strongholds of white European civilization in resistance against Muslims and Western aggressors" (Lažetić, 2018: 58). The Russian far-right ideologue Alexander Dugin, author of the Fourth Political Theory, is often seen in Serbia with Jim Dowson, founder of Britain First, and the former British National Party leader Nick Griffin, who have been "exiled" from Europe: "Serbia is becoming a 'conference room' where Russian and European far right activists connect and strategize together" (ibid.: 49).

The securitization of migration needed agency personifying it. Precisely such an agency was created in the person of heroized and mediatized vigilantes "catching" refugees (Krasteva 2020) or "arresting" refugees - vigilantes such as "the so-called 'people's patrols' in Belgrade in February 2020. Under the patronage of the far-right organization 'No Surrender of Kosovo and Metohija,' groups of young men intercepted migrants on several locations in the city, forbidding them to move around in the evenings and threatening them with radical countermeasures" (Ejdus and Rečević 2021: 37). Incidents and attacks against asylum seekers have also been reported by the media in Kosovo. ${ }^{4}$ Vigilantes as a civic agency of anti-migration attitudes are a bridge to bottom-up securitization.

4 I thank Prof. Vjollca Krasniqi for this information. 
In August 2017 dozens of worried parents took to the streets of Šid, a town on the Serbian-Croatian border. They were triggered by a rumour that illegal migrants from the Middle East and Africa who were crossing the Balkans on their way to Western Europe were going to be integrated into schools and hence permanently settle in Serbia... Anxieties triggered by this rumour drove citizens of this small town for the first time in two years to the streets in opposition to the government's open-door policy towards the migrants. This spontaneous outburst of anxiety remained puzzling since no similar anti-migrant mobilization had been recorded in either Šid or the rest of Serbia until that moment while political elites had not issued statements that could have triggered it. Ever since, similar outbursts of anti-migrant sentiment and mobilization have occurred in several other cities across Serbia.

EJDUS AND REČEVIĆ 2O21: 29

I have included this long quote because it illustrates three key characteristics of bottom-up securitization. The first is the temporality of bottom-up securitization. During the extremely intensive migration flows along the Western Balkan route there were no anti-immigrant mobilizations. Even the elections in 2016 and 2017 did not turn migration into a key campaign issue (Ejdus and Rečević 2021: 34). The anti-migration protests in Serbia began after the peak of the crisis - in 2017 - and intensified later, in 2019-2020 (ibid.: 36). The second characteristic is the random character of the anti-immigrant mobilization, which was not provoked by migration policies or by a significant change in the migration situation, but by the perennial favourite - rumours. This contingency, not "logical" temporality, is conceptualized as "emergence": "when a threshold is met, a small change can lead to a tipping point with dramatic effects and the emergence of new patterns" (Ejdus and Rečević 2021: 31, citing Kaufmann 2017: 5). The third characteristic is key for understanding the first two: ontological insecurity, the fear that migrants can disrupt the life-worlds and cohesion of the local community. Ontological insecurity is concerned not with the numbers but with the intentions of migration flows, and becomes especially intensive not so much when there is transit migration, but rather when there is a probability of settlement. It must be noted that the latter is not factual but imagined - neither during nor since the end of the migration crisis have refugees wanted to settle permanently in the Balkans. On the contrary, the overwhelming majority try to leave the Balkans as quickly as possible (Ejdus and Rečević 2021). An insignificant number of refugees, not only in Serbia but also along 
the Balkan route, apply for asylum (Šalamon 2016; Župarić-Iljić and Valenta 2019). ${ }^{5}$ But the imagined danger of settlement is experienced as a threat to the local religious and ethnic identity. It activates and catalyzes the culture of constant danger (Foucault 2003). How are the feelings of ontological insecurity and bottom-up securitization correlated to populist top-down securitization? There are two rival, alternative interpretations in this regard. According to the first one, the causal chain starts bottom-up and ontological insecurity is the base of the pyramid on which far-right actors subsequently build, ending in restrictive policies: the arrival of migrants might produce ontological insecurity among the host population which can fuel the success of far-right parties and lead to the implementation of anti-immigrant policies (Kaufmann 2017: 7). This author is a proponent of the polar opposite interpretation, and thinks that populist top-down securitization provides the framework and terms of interpreting migration as a security threat, invasion, crisis (Krasteva 2019b, 2020). In Serbia - as in many other Balkan and European countries - the refugee crisis was transformed from a humanitarian into a securitarian crisis, while solidarity was transformed into anxiety and anti-immigration mobilizations.

\subsubsection{Mainstreaming of Far-right Securitization}

Mainstreaming of the far right is a political oxymoron. However, it expresses a real tendency towards hegemonization of the anti-immigration discourse and its adoption by a number of mainstream political parties and leaders. In Croatia, the humane/humanitarian approach taken at first was eventually replaced, with the gradual closure of the corridor, by "radicalization and securitization of state discourses, rhetoric and politics" (Župarić-Iljić and Valenta 2019: 151). In Serbia, Marina Lažetić (2018) points out as an example the political party Dosta je bilo (Enough is Enough), which entered parliament in 2016 as one of the most liberal parties but later made a volte-face in 2018 and turned to virulent chauvinism. Ever since, one of their central narratives has been that the Serbian government is covering up a plan to settle the migrant 'invaders' (ibid.). Elections often catalyze securitization. On the eve of the April 2020 elections in Serbia, official Belgrade hardened its discourse, shifting from a more open to a restrictive policy: President Vučić declared "that Serbia 'is not going to become a parking lot for migrants' [and went on to add:] 'If necessary we are capable of closing the border"' (Euractiv 2020). The mainstreaming of far-right securitization means that the anti-immigration discourse, which used

5 In Bosnia and Herzegovina in 2018, out of 23,902 migrants just 1,567, or 6\%, applied for asylum; in 2019 the number was even smaller - 784 asylum applications out of 29,302 migrants, or 3.7\% (Hodžić 2020: 88-89). 
to be marginal, has become hegemonic and that the public sphere is dominated by the far-right interpretation of the refugee crisis not as a humanitarian problem but as a security threat. This discursive shift has direct policy implications: the special nature of security threats usually justifies the use of extraordinary measures - such as involving the army, intelligence, and police forces in migration management, intensifying border controls, increasing counterterrorism activities, installing razor wire, and making asylum policy stricter (Buzan, Wæver, and de Wilde 1998). This thesis of the Copenhagen School of security studies explains how securitization, intensified by the Covid-19 pandemic, "facilitated the militarization of the migration response in Serbia, allowing the introduction of the measures which had been improbable under the previous circumstances. For the first time since the outbreak of the crisis, all migrants registered in reception centers were detained while the military was deployed to safeguard all reception camps in Serbia" (Ejdus and Rečević, 2021: 38).

\subsection{B/Ordering the Migration Crisis}

The migration crisis has been translated politically as a border crisis both through policies (externalization of European border management to the Western Balkans) and through politics - domination of images and imaginaries of borders, walls, fences. ${ }^{6}$ The Balkans turned into a zone of overproduction of border fences: between Bulgaria and Turkey in April 2015, Hungary and Serbia in September 2015, Macedonia and Greece in November 2015, Slovenia and Croatia in November 2015, Austria with Slovenia in December 2015 (Hodžić 2020: 79-80). The migration crisis as a border crisis mobilizes the symbolic capital of the triad Bordering/Ordering/Othering (Houtum and Naersen 2002) - overproduction of borders and boundaries, the distinctions Us vs Them, and the strengthening of "order" (there is a place for everybody, but everybody should stay in his or her place). B/Ordering the migration crisis strengthens two types of power (Foucault 2003): sovereignty and discipline. While sovereign power targets the safety of the sovereign and his or her territory, disciplinary power targets individual bodies in their separation and surveillance.

B/Ordering the migration crisis performs two different, but equally important functions: a political and a symbolic one. It legitimizes the double agency of the $\mathrm{b}$ /ordering - the populist politicians and the vigilantes guarding borders. The border they are both guarding is less the national than the symbolic

6 For the deconstruction of "the language of walls" by public intellectuals in Serbia and Croatia, see Sicurella (2018). 
border dividing Us-Them; national borders are increasingly conceived in religious and ethnic terms; increasingly, politics of migration, politics of security, and politics of identity interfere. The political implication of the combined effect of Bordering/Ordering/Othering is the affirmation of the Schmittian concept of the political as an arena of foes (Schmitt 2007).

\section{4 \\ Post-crisis Management - The Case of Policy on Foreign Fighters' Repatriation in Kosovo}

There are also country-specific policies of post-crisis management. The most emblematic example is the repatriation of foreign fighters in Kosovo.

After the defeat of the so-called Islamic State (IS), a number of governments were faced with the challenge of what policy they should follow with regard to their citizens who had been involved in the conflict. Is had managed to draw in more than 40,0oo foreign fighters - including men, women, and children from over 110 countries, some 5,000 of whom originated from Europe. An estimated 403 Kosovars joined the conflict in Syria and Iraq, including 255 men. Around 76 children with at least one Kosovar parent were born in the foreign conflict zones (Clingendael 2020: 1-2). Unlike most other foreign fighters from Europe, who were of immigrant origin and often had dual citizenship, those from Kosovo were "simply Kosovars" (ibid.: 4).

The UN published guidelines in 2019 that made clear that states have the primary responsibility for their own nationals, but overwhelmingly the European response has been to refuse to actively repatriate their citizens, "with the UK and Denmark opting to strip citizenship from its nationals, Belgium and France taking back a small number of orphaned children, and the Dutch Court of Appeal ruling that the state was not legally required to assist in the repatriation of children" (Clingendael 2020: 1). Kosovo, however, applied a different policy and "repatriated 110 citizens, including men, women, and children, in April 2019, making it one of a very small number of countries that has actively repatriated citizens involved with the Islamic State" (ibid.). The total number of Kosovo returnees through formal and informal channels is believed to be 242 , of which 124 are men, 38 women, and 8 o children. Kosovo's policy on repatriated and returnee foreign fighters combined punitive and reintegration measures:

Around 20 of the women returnees have so far been indicted, 18 of them charged with "organising and participating in a terrorist group," with the other two charged with "joining or participating in foreign military or po- 
lice..." ... The overwhelming majority of the male returnees have been prosecuted, and those who were convicted received on average 3.5 years in prison. It should be noted that sentences have been higher (up to 10 years) for recruiters or those who plotted terrorist attacks, some of whom never travelled to foreign conflict zones.

CLINGENDAEL 2O2O: $3-4$

Women and children are reintegrated through special education classes, counselling, and other measures.

Kosovo is an interesting case of post-crisis management of foreign fighters in several respects. A country with a population of 1.8 million had the courage to repatriate 110 foreign fighters in one go, while the other European countries have found it difficult to manage the approximately 800 foreign fighters who have remained in Syria. This asymmetry is intensified by the fact that the institutional capacity of the youngest state in Europe is incomparably smaller than that of the EU member countries. Another aspect of Kosovo's pro-active policy is also noteworthy: "In 2015, Kosovo became the first country in the Western Balkans to pass entirely new legislation to prohibit joining armed conflicts outside of state territory" (Clingendael 2020: 2).

It is still too early to conclude whether Kosovo's proactive policy combining punitive, rehabilitation, and reintegration measures will prove effective. Two other conclusions are important for this analysis. The first concerns the capacity of Kosovo and the Western Balkans for policy innovation in post-crisis management - moreover, in such a sensitive sphere. The second concerns the inversion in the usual situation, with the Western Balkans transferring policies and good practices to the EU, instead of vice versa. In this case the EU is watching with interest Kosovo's experience in post-conflict management and reintegration of foreign fighters.

\section{Beyond Crises, or How to Change the Region's Migration Profile through the Diaspora and Development Nexus}

How can the migration profile of a region be changed - from below, by changing the migration flows, or from above, by changing and adopting a new migration policy? The theoretical answer to this dilemma is beyond the scope of this study. For the purposes of this article, I will elaborate on the second perspective, asking which the most significant change in migration policy is, how it has been institutionalized, and what type of migration profile of the Western Balkans it constructs. 
The most significant policy innovation in this regard can be summarized as a transition from management of refugee crises and irregular migration to promotion of the diaspora and development nexus. This policy turn is based on a new understanding of diaspora. Whereas diaspora is traditionally associated with trauma, exile, memory (Safran 1991), the new understanding of diaspora is optimistic, constructive, and associated with development: "wings of development," "heroes of development" (Castles and Delgado 2008). The second aim of the migration management shift is the transition from "drain" to "gain," from emigration as a loss of demographic and social capital to diaspora engagement: "Skilled youth migration might be transformed into 'brain gain' and 'gain circulation' taking into account the migration-development nexus." (Bobic, Veskovic Andjelkovic 2019: 255).

"Engage, Enable, Empower" (Krasteva et al. 2018: 96) - this slogan of Albania's policy on diaspora engagement sums up its strong potential impact. The policy on diaspora engagement has been institutionalized in different forms in the different countries of the Western Balkans, ranging from the highest level, such as the State Ministry for Diaspora in Albania and the (former) Ministry of Diaspora ${ }^{7}$ in Kosovo, to that of Minister without Portfolio in North Macedonia or the Diaspora Sector at the Ministry of Human Rights and Refugees in Bosnia and Herzegovina. These are supported by various laws and strategies. Among the interesting legislative changes in this regard is the Law on Financial Support of Investments, adopted in North Macedonia in 2018, "which stipulates that a diaspora investor is entitled to receive a $10 \%$ subsidy of the amount of the investment" (ibid.: 54).

The policy of diaspora engagement has two ambitious goals: to focus migration policy on a key regional characteristic - significant emigration in terms of numbers and impact; and to change the migration profile in a positive direction. The number of Albanian emigrants is higher than the resident Albanian labour force, while the diasporas of $\mathrm{B} \& \mathrm{H}$ and Kosovo are estimated at half their respective populations (MIGREC 2020). The new policy is designed to transform at least part of this huge demographic loss into a potential for development of the sending countries through enhancing regional labour mobility. Whereas the policy on diaspora engagement is targeted primarily at migration

7 Kosovo's Ministry of Diaspora was closed down in 2020, not because of a downgrading of the policy on diaspora but because of the restructuring of the Council of Ministers. Currently the respective policy is managed by the Ministry of Foreign Affairs and Diaspora. Diaspora played a crucial role in the 14 February 2021 elections. I thank Prof. Vjollca Krasniqi for this clarification. 
to Western destinations, the second policy of the migration and development nexus is targeted at regional labour mobility. The "soft connectivity" agenda is the new political project for strengthening regional cooperation, launched by the European Bank for Reconstruction and Development (Levitin and Sanfey 2018: 1). This is the most important goal of the Berlin Process. Its objective is to make the region more competitive on the global investment map and to enable economic growth, thus bringing stability and development. Enhancing regional mobility is the third pillar of the new policy - "advocating free movement of people" - along with removing trade barriers, highlighting investment opportunities and synergies, and developing digital integration. This strategy of the European Research Executive Agency (REA) contributes to a common labour market, in order to partially solve regional unemployment issues (in 2020 , Western Balkans unemployment rates range from $12.72 \%$ in Serbia ${ }^{8}$ and $12.81 \%$ in Albania ${ }^{9}$ to $29.5 \%$ in Kosovo ${ }^{10}$ ) and make a step forward in the prevention of brain drain from an area with low ability to retain talent, as it would open up more employment opportunities within the region. The REA promotes a policy of economic liberalization - capitals and market first, people second. Labour mobility within the region is aimed at ensuring that the right skills are available to support the investments undertaken (Krasteva et al. 2018).

Despite the neo-liberal economic logic, the regional mobility policy contributes to overcoming the crisis profile of the Western Balkans in three regards: it brings political visibility to the regional character of Balkan migrations; illustrates the policy shift from crisis management to labour mobility policy; and enhances post-conflict reconstruction of the region from below.

The policies of irregular migration and crisis management have invisibilized the highly regional character of immigration: the majority of immigrants in the Western Balkans are from neighbouring countries, not third-country

8 https://www.statista.com/statistics/440532/unemployment-rate-in-serbia/\#: :text=In\%2O $2020 \% 2 \mathrm{C} \% 20$ the\%2ounemployment\%2orate,was\%2oat\%2oapproximately\%2012.72\%20 percent.

9 https://www.google.com/search?q=unemployment+Albania+2020\&sxsrf=ALeKko1-mdh7orUCNoGiLNG_G-d38-Ang\%3A1619698272116\&ei=YKKKYKyvBsT6qwHr5aHoDA\& oq=unemployment+Albania+2O2o\&gs_lcp=Cgdnd33td2l6EAMyBggAEAgQHjo HCAAQRxCwAzoGCAAQBxAeOggIABAHEAUQHjoICAAQCBAHEB $5 \mathrm{Q}_{3} \mathrm{~B}_{5} \mathrm{Y}$ vDNg1zloAXACeACAAccBiAGcDpIBBDMuMTGYAQCgAQGqAQdnd3Mtd2l6yAEI wAEB\&sclient=gws-wiz\&ved=oahUKEwis 35 uhtqPwAhVE_SoKHetyCMoQ4dUDCA4\& uact $=5$.

10 https://www.ceicdata.com/en/indicator/kosovo/unemployment-rate\#: :text=Kosovo\%2O Unemployment\%2oRate\%2oincreased\%2oto,an\%2oaverage\%2orate\%2oof\%2o $28.70 \% 20 \% 25$. 
nationals. Serbia is emblematic in this sense: nearly one-third (31\%) of immigrants originate from Bosnia and Herzegovina, $17.2 \%$ from Montenegro, and 9.1\% from Croatia. Immigration primarily consists of Serbians that moved from surrounding countries. Four Western Balkan countries (Serbia, Croatia, Montenegro, and North Macedonia) are among the top ten countries whose residents have received work permits in Bosnia and Herzegovina. The migration profiles shift in relation to the scale of analysis. For instance, Serbia is a sending country at a European scale while it is a receiving country at the regional scale. Similarly to most migration outflows, several intra-regional flows are also asymmetrical: North Macedonia has a stock of Western Balkan immigrants larger than its Western Balkan diaspora; a small percentage (4.5\%) of Serbian emigrants live in the region, while immigration to Serbia is primarily regional. ${ }^{11}$ In opposition to the asymmetry of most regional flows, there seems to be symmetric exchange of workers; for example, the regular circulation of labour force between Albania and Kosovo. Three countries are the most attractive destinations for regional labour migration and mobility: Slovenia, Croatia, and Montenegro (Krasteva et al. 2018).

This policy facilitates post-conflict reconstruction through mobility, as well as development of an economically and politically stable region through freer and more flexible labour mobility. Crucial for this reconstruction from below is the youth. The regional immigration is mostly a youth phenomenon - the largest share (6o-65\%) of regional immigrants belongs to those aged 24-49 (Krasteva et al. 2018: 100). Another positive effect is the policy shift from management of irregular migration and refugee crises to the migration and development nexus, from the "dramatic" to a positive understanding of migration, and from vulnerable to empowered migrants. ${ }^{12}$

The policy of promoting the diaspora and development nexus is still more of an ambitious programme than an effective practice (Krasteva et al. 2018: 100), but it is important for the purposes of this study in three respects. First, it demonstrates both an external and internal political will - of the governments in the Western Balkan region as well as of the EU - for overcoming the crisis image of the Western Balkans. Second, it demonstrates the region's capacity for policy innovation and for initiating a new institutionalization of migration management. Third, it contributes to the transformation of the political

11 The immigration to Serbia from the region has been declining recently, e.g. in the period 2010-2018. Thanks to the reviewer for this relevant information.

12 Policies that empower irregular migrants and asylum seekers, instead of their "management," are needed, because EU is not willing to accept all of them and some refugees might decide to stay. Integration as a two-way process of accommodating immigrants and changing local attitudes is necessary. Thanks to the reviewer for this relevant comment. 
conception of migration from an expression and element of crises, conflicts, and wars into a factor for regional post-conflict reconstruction and for national and regional development.

\section{Conclusion - the Migration Crises in a Comparative Perspective}

The migration profile of the Western Balkans is very dynamic, with the pendulum shifting from refugee crises to a migration and development nexus. The comparative analysis of the four refugee and migration crises in the Western Balkans since the mid-199os points to several characteristics and trends (see Table 2).

As the above table illustrates, the Balkan migration crises in the last three decades are numerous and diverse. They differ significantly by size of migration flows - the largest are those caused by the Yugoslav wars and conflicts of the

TABLE 2 Comparison of the Balkan refugee \& migration crises (1990-2020)

\begin{tabular}{|c|c|c|c|c|c|}
\hline $\begin{array}{l}\text { Refugee/ } \\
\text { migration } \\
\text { crisis }\end{array}$ & Period & Origin & Destination & Nationality & Duration \\
\hline $\begin{array}{l}\text { Yugoslav } \\
\text { wars and } \\
\text { conflicts }\end{array}$ & 1991-2001 & Regional & $\begin{array}{l}\text { Western } \\
\text { Balkans } \\
\text { Western } \\
\text { Europe }\end{array}$ & $\begin{array}{l}\text { Bosniaks, } \\
\text { Serbs, } \\
\text { Croats, etc. }\end{array}$ & Several years \\
\hline $\begin{array}{l}\text { Western } \\
\text { Balkan } \\
\text { Refugee } \\
\text { Route }\end{array}$ & $2015-2016$ & $\begin{array}{l}\text { Middle East } \\
\text { and other } \\
\text { conflict } \\
\text { regions }\end{array}$ & $\begin{array}{l}\text { Western } \\
\text { Europe }\end{array}$ & $\begin{array}{l}\text { Syrians + } \\
\text { others }\end{array}$ & $\begin{array}{l}\text { Several } \\
\text { months }\end{array}$ \\
\hline Outbreaks & $\begin{array}{l}\text { Recent } \\
\text { years }\end{array}$ & Diverse & $\begin{array}{l}\text { Western } \\
\text { Europe }\end{array}$ & $\begin{array}{l}\text { Kosovars, } \\
\text { Morrocans, } \\
\text { Pakistanis, } \\
\text { Afghans, } \\
\text { etc. }\end{array}$ & $\begin{array}{l}\text { From ad hoc } \\
\text { to trends }\end{array}$ \\
\hline $\begin{array}{l}\text { Populist } \\
\text { migration } \\
\text { crisis }\end{array}$ & $\begin{array}{l}\text { Populist } \\
\text { political } \\
\text { temporality }\end{array}$ & $\begin{array}{l}\text { Non- } \\
\text { European }\end{array}$ & $\begin{array}{l}\text { Western } \\
\text { Europe }\end{array}$ & $\begin{array}{l}\text { Ethnic, } \\
\text { Religious, } \\
\text { Cultural } \\
\text { Others }\end{array}$ & $\begin{array}{l}\text { Depending } \\
\text { on the popu- } \\
\text { list agency }\end{array}$ \\
\hline
\end{tabular}

SOURCE: AUTHOR'S ELABORATION 
199os, which led to the forced displacement and migration of approximately $10 \%$ of the population of the Western Balkans. The smallest are a number of migration outbreaks in recent years, ranging from several hundred to several thousand migrants. In-between those two poles are the refugee flows during the Western Balkan Refugee Route in 2015-2016, when about one million refugees crossed the region. The populist migration crisis is the least dependent on the number of refugees, as attested by the fact that it has often emerged not during but after the peak of the refugee crisis.

The national profile of migrants also varies. It is radically different in the first two crises - during the Yugoslav wars and conflicts the Western Balkans were both a source and a destination of refugee flows made up of citizens of the countries in the region. During the Western Balkan Refugee Route the refugee flows were from Syria, Afghanistan, and other distant countries in conflict zones. Migration outbreaks have an eclectic profile and include people from the region, such as Kosovars and Albanians, as well as refugees from the Middle East, Asia, and North Africa. The populist crisis targets primarily migrants from more distant countries with a different ethnic, language, religious, and cultural profile.

The duration of the Balkan migration crises also varies significantly - about half a year during the Western Balkan Refugee Route, and a decade in the case of the forced migrations during the Yugoslav wars and conflicts, which continued with return migration after the end of these conflicts. The duration of migration outbreaks is more indefinite - just several months in some cases, such as those of Albanians and Kosovars migrating to Germany; and in others turning from ad hoc into a trend, as in the new transit refugee wave in Bosnia and Herzegovina. As for the populist migration crisis, it is characterized by a fluid temporality.

Agency also differs in the different crises. The first three types of migration crises (during the Yugoslav wars and conflicts, the Western Balkan Refugee Route, and migration outbreaks) are characterized by two main types of agency - refugees and policymakers managing the crisis. There is a third important type - civic agency of solidarity - but it is discussed elsewhere (Krasteva, Saarinen, and Siim 2019). The populist migration crisis has introduced the agency of securitization. Securitization itself unfolds both top-down - initiated by far-right and populist politicians - and horizontally, initiated by vigilantes or citizens as exponents of ontological insecurity and anxiety of otherness.

The comparative analysis of the refugee and migration crises in the Western Balkans in the last three decades (1990-2020) points to several trends: 
- Transition from a refugee wave caused by a military conflict in the region to refugee flows caused by military and other conflicts in distant regions, such as the Middle East, Central Asia, etc.

- Transition from large-scale refugee crises spanning several countries of the Western Balkans and characterized by large flows, such as those during the Yugoslav wars and the Syrian crisis, to smaller, local flows originating from different countries, such as those of Moroccans to Montenegro and Kosovars to Germany.

- Transition from a dual migration profile of a both sending and receiving region in the mid-199os to a transit destination at present.

- Transition from "real" refugee crises characterized by big migration flows and institutional in/capacities of managing them to populist crisis securitizing migration as a threat to national security and a challenge to ontological in/security.

At the opposite - positive - pole of the migration profile, we may place some interesting practices of post-conflict management, as well as the policy of promoting the migration and development nexus. An example of the former is Kosovo's experience in repatriation from Syria and rehabilitation of foreign fighters and their families. The latter is an expression of the political will to turn the defect into an effect, to transform the loss of demographic, intellectual, social, and democratic capital because of emigration into a factor of development by attracting diaspora members as investors or experts through various innovative forms such as "virtual return" or "think nets" (Bobic, Veskovic Andjelkovic, 2019). The diaspora engagement policy can be summarized by the paradox between strong symbolism and uncertain policy results. This paradox is due to the tension between patriotism and state capture, between the desire of many diaspora members to contribute to the development of their native local communities and homeland, on the one hand, and corruption and inefficiency of the public administration which delays or hinders the implementation of numerous initiatives on the other.

The migration profile of the Western Balkans remains split between the poles of past and present migration crises and the migration and development nexus, between real and constructed migration crises, between securitized migration as a catalyst of an alleged national threat and ontological insecurity and migration as a factor for post-conflict reconstruction, integration, and prosperity of the region. 


\section{References}

Andersson, R. 2014. "Time and the Migrant Other: European Border Controls and the Temporal Economics of Illegality," American Anthropologist 116 (4): 795-8og.

Baas, M., and B.S.A. Yeoh. 2019. "Introduction: Migration studies and critical temporalities," Current Sociology 67 (2): 161-68.

Baldwin-Edwards, M. 2005. "Balkan Migrations and the European Union: Patterns and Trends," Romanian Journal of European Studies 4: 31-44. https://mpra.ub.unimuenchen.de/159o/1/MPRA_paper_159o.pdf.

Bauman, Z., and C. Bordoni. 2004. State of Crisis (Cambridge: Polity Press).

Bobic, Veskovic Andjelkovic 2019. "Skilled Youth Emigration from Serbia in Developmental Perspective," Southeastern Europe, Vol 43, 255-276.

Bonifazi, C., and M. Mamolo. 2004. "Past and Current Trends of Balkan Migrations," Espace, Populations, Sociétés 3: 519-31.

Braudel, F. 1980. "History and the Social Sciences: The Longue Durée," in On History (trans. Sarah Matthews ; Chicago: University of Chicago Press, 1980 [French original, 1958]): 25-54.

Buzan, B., O. Wæver, and J. de Wilde. 1998. Security: A New Framework for Analysis (Boulder: Lynne Rienner Publishers).

Castles S. and Delgado Wise R. (eds). 2008. Migration and Development: Perspectives from the South (Geneva: IOM).

Castles, S., H. de Haas, and M.J. Miller. 2014. The Age of Migration: International Population Movements in the Modern World (New York: Guilford Press, $5^{\text {th }}$ ed.).

Clingendael. 2020. What EU member states can learn from Kosovo's experience in repatriating former foreign fighters and their families. Policy Brief. https://www. clingendael.org/sites/default/files/2020-06/Policy_Brief_Kosovo_experience_ repatriating_former_foreign_fighters_May_2020.pdf.

Constantopoulou, C. (ed.). 2017. Récits de la crise: Mythes et réalités de la société contemporaine (Paris: L'Harmattan).

Cwerner, S.B. 2001. "The Times of Migration," Journal of Ethnic and Migration Studies $27(1): 7-36$.

Dobry, M. 2009. Sociologie des crises politiques. La dynamique des mobilisations multisectorielles (Paris: Presses de Sciences Po, Kindle ed.).

DW. 2020. "Fire at Bosnia migrant camp, authorities blame residents," DW, 23 December. https://www.dw.com/en/fire-at-bosnia-migrant-camp-authorities-blame-residents/ a-56047531.

DW. 2021. "Bosnia moves migrants into heated tents after snowstorm," $D W, 8$ January. https://www.dw.com/en/bosnia-moves-migrants-into-heated-tents-after-snowstorm/ $\mathrm{a}-56177032$. 
Ejdus, F., and T. Rečević. 2021. "Ontological Insecurity as an Emergent Phenomenon: Bottom-Up Securitization of Migration in Serbia," European Psychologist 26 (1): 2944. https://psycnet.apa.org/record/2021-27826-oo4.

Eraly, A. 2017. "Légitimité de la crise, crise de la légitimité," in Constantopoulou 2017: 51-58. ESPON EFTC. 2018. MIGRATUP - Territorial and Urban Potential Connected to the Migration and Refugee Flows. https:/www.espon.eu/sites/default/files/ attachments/MIGRATUP_FinalMainReport.pdf.

Euractiv. 2O2O. "BELGRADE - 'We can close the border but people have no reason to fear migrants," Euractiv, 6 March. https:/www.euractiv.com/section/all/short_news/ belgrade-we-can-close-the-border-but-people-have-no-reason-to-fear-migrants/.

Foucault, M. 2003. "Society Must Be Defended": Lectures at the Collège de France (1975-76) (trans. David Macey ; New York: Picador, 2003 [French original, 1997]).

Fukuyama, F. 1992. The End of History and the Last Man (New York: Free Press).

Frucht, R. C. 2005. Eastern Europe: An Introduction to the People, Lands, and Culture (Santa Barbara, California: ABC-CLIO).

Gardiner Barber, P., and W. Lem. 2018. "Migration, Temporality and Capitalism: A Brief Introduction," in P. Gardiner Barber and W. Lem (eds), Migration, Temporality, and Capitalism: Entangled Mobilities across Global Spaces (Cham: Palgrave Macmillan):1-20. Hodžić, K. 2020. "Understanding the migrant crisis in Bosnia and Herzegovina," Criminal Justice Issues - Journal for Criminalistics, Criminology and Security Studies $20(5): 77-98$.

Houtum, van H., and T. van Naerssen. 2002. "Bordering, Ordering and Othering," Tijdschrift voor Economische en Sociale Geografie 93 (2): 125-36.

Human Rights Watch. 1997. Human Rights in Eastern Slavonia during and after the transition of authority. https://www.refworld.org/docid/3ae6a7f7o.html.

Iacopino, V., M. Frank, H.M. Bauer and A. S. Keller. 2001. "A Population-Based Assessment of Human Rights Abuses Committed Against Ethnic Albanian Refugees From Kosovo," American Journal of Public Health 91 (12): 2013-2018.

Kaufmann, E. 2017. "Complexity and Nationalism," Nations and Nationalism 23 (1): 6-25. Kavalski, E. 2007. "The Fifth Debate and the Emergence of Complex International Relations Theory: Notes on the Application of Complexity Theory to the Study of International Life," Cambridge Review of International Affairs 20 (3): 435-54.

King, R. 2005. "Albania as a Laboratory for the Study of Migration and Development," Journal of Southern Europe and the Balkans 7 (2): 133-55.

Krasteva, A. 2015. "Mobile Balkans: Temporality, Types, Trends," Glasnik Etnografskog instituta 63 (3): 515-35. https://www.researchgate.net/publication/ 290212963_Mobile_Balkans_Temporality_types_trends.

Krasteva, A. 2019a "Book review of Žagar, Igor Ž., Šalamon, Neža Kogovšek and Hacin, Marina Lukšič (eds). The Disaster of European Refugee Policy: Perspectives from the 'Balkan Route'. Cambridge Scholars Publishing, 2018," Southeastern Europe 43 (3): $335^{-37}$. 
Krasteva, A. 2019b. "Post-democratic Crisis and Political Leadership. From Crisis Management to Crisis Creation," in S. Salvatore et al. (eds), Symbolic Universes in Time of (Post)Crisis: The Future of European Societies (Cham: Springer): 3-23.

Krasteva, A. 2020. "If Borders Did Not Exist, Euroscepticism Would Have Invented Them, or on Post-Communist Re/De/Re/Bordering in Bulgaria," GeoPolitics 25: 678-705.

Krasteva, A., A. Haxhikadria, D. Marjanovic, M. Petreski, and N. Oruc. 2018. Maximising the Development Impact of Labour Migration in the Western Balkans. Final Report (Brussels: IBF International Consulting, The European Union's IPA Programme for Balkans Region). http://wb-mignet.org/wp-content/uploads/2019/10/Final-report_ Maximising-development-impact-of-labour-migration-in-WB_0412018-1.pdf.

Krasteva, A., and A. Membretti. 2020. "The New Pact on Migration and Asylum: From Strategic Document to Sense-rich Policy and Innovative Practices," in Recommendations from the Members of the TEPSA Network to the Incoming Portuguese Presidency 3. http://www.tepsa.eu/wp-content/uploads/2020/11/TEPSARecommendations-to-the-Portuguese-Presidency.pdf.

Krasteva A., A. Saarinen, and B. Siim. 2019. "Citizens' Activism for Reimagining and Reinventing Citizenship Countering Far-Right Populism," in B. Siim, A. Krasteva, and A. Saarinen (eds), Citizens' Activism and Solidarity Movements: Contending with Populism (Palgrave Studies in European Political Sociology; Cham: Palgrave Macmillan): 265-92.

Krzyżanowski, M., A. Triandafyllidou, and R. Wodak. 2018. "The Mediatization and the Politicization of the 'Refugee Crisis' in Europe," Journal of Immigrant \& Refugee Studies 16 (1-2): 1-14.

Laczko, F., A.K. von Koppenfels, and J. Barthel. 2002. "Trafficking in Women from Central and Eastern Europe: A Review of Statistical Data," in F. Laczko, I. Stacher, and A.K. von Koppenfels (eds), New Challenges for Migration Policy in Central and Eastern Europe (The Hague: IOM, TMC Asser Press): 153-74.

Lažetić, M. 2018. "'Migration Crisis' and the Far Right Networks in Europe: A Case Study of Serbia," Journal of Regional Security 13 (2): 131-78.

Levitin, O., and P. Sanfey. 2018. Regional Cooperation in the Western Balkans (London: EBRD). https://www.ebrd.com/documents/eapa/western-balkans-summit-2018paper.pdf.

MIGREC. 2020. Mapping of migration related research and policy development in the Western Balkan Countries - Report on prospective regional networks. https://migrec. fpn.bg.ac.rs/wp-content/uploads/2020/o4/Deliverable-1.3.pdf.

Mitchell, M. 2009. Complexity: A Guided Tour (Oxford: Oxford University Press).

Revault d'Allonnes, M. 2012. La crise sans fin. Essai sur l'expérience moderne du temps (Paris: Seuil). 
Rowland, J. 2000. "Bleak outlook for Serb refugees", in BBC News. Belgrade. 22 March 2000.

Ruhs, M., K. Tamas, and J. Palme. 2019. "Introduction: Making Linkages between Research, Public Debates, and Policies on International Migration and Integration," in M. Ruhs, K. Tamas, and J. Palme (eds), Bridging the Gaps: Linking Research to Public Debates and Policy-making on Migration and Integration (Oxford: Oxford University Press): 1-20.

Safran, W. 1991. "Diasporas in Modern Societies: Myths of Homeland and Return," Diaspora: A Journal of Transnational Studies 1 (1): 83-99.

Sicurella, F.G. 2018. "The Language of Walls Along the Balkan Route," Journal of Immigrant \& Refugee Studies 16 (1-2): 57-75.

Schmitt, C. 2007. The Concept of the Political (trans. George Schwab ; Chicago: University of Chicago Press, 2007 [German original, 1932]).

Schulz, M. 2017. "La crise et la politique des avenirs," in Constantopoulou 2017: 9-19.

Spurk, J. 2017. "Récits de crise, récits d'affinités électives," in Constantopoulou 2017: $67-72$.

Stanicek, B. 2019. "Situation of migrants in Bosnia and Herzegovina," European Parliament Think Tank, 14 November. https://www.europarl.europa.eu/thinktank/ en/document.html?reference=EPRS_BRI(2019)644174.

Šalamon, N.K. 2016. "Asylum Systems in the Western Balkan Countries: Current Issues," International Migration 54 (6): 151-63.

Triandafyllidou, A. 2018. "A 'Refugee Crisis' Unfolding: 'Real' Events and Their Interpretation in Media and Political Debates," Journal of Immigrant \& Refugee Studies 16 (1-2): 198-216.

UNHCR.1993. The State of the World's Refugees. 1993.

UNHCR. 2004. Profile of Internal Displacement: Macedonia. 26 February 2004.

US Department of State. 1994. Croatia Human Rights Practice. 1993.

Vezovnik, A. 2018. "Securitizing Migration in Slovenia: A Discourse Analysis of the Slovenian Refugee Situation," Journal of Immigrant \& Refugee Studies 16 (1-2): 39-56.

Watkins, C. S. 2003. The Balkans. (Hauppauge, New York: Nova Publishers).

Wodak, R. 2014. The Language of Walls. Resemiotizing European Identity and Border Politics. Keynote speech at CADAAD 2014 (Budapest: Hungary).

Wodak, R. 2015. The Politics of Fear. What Right-Wing Populist Discourses Mean (London: Sage).

Žagar, I.Ž., N.G. Šalamon, and M.L. Hacin (eds). 2018. The Disaster of European Refugee Policy: Perspectives from the "Balkan Route" (Newcastle upon Tyne: Cambridge Scholars Publishing).

Župarić-Iljić, D., and M. Valenta. 2019. "Opportunistic Humanitarianism and Securitization Discomfort Along the Balkan Corridor: The Croatian Experience," in M. Feischmidt, L. Pries, and C. Cantat (eds), Refugee Protection and Civil Society in Europe (Cham: Palgrave Macmillan): 129-6o. 